Neuroepidemiology 2008;31:270

DOI: $\underline{10.1159 / 000165367}$

\section{Glial Brain Tumors}

Olufemi E. Idowu

Division of Neurological Surgery, Department of Surgery, Lagos State University College of Medicine and Lagos State University Teaching Hospital, Ikeja, Nigeria

The term 'glioma' refers to tumors thought to be of glial cell origin and includes astrocytic tumors [World Health Organization astrocytoma classification of grades I, II (astrocytoma), III (anaplastic astrocytoma) and IV (glioblastoma multiforme)], oligodendrogliomas, ependymomas and mixed gliomas [1-3].

Although there has been an increase in the number of epidemiological studies of glioma, little consensus exists regarding the nature and magnitude of risk factors contributing to its development. In addition, there are differences in methods, eligibility criteria used and representative patients studied. Other confounding factors include the variable use of proxies to report information about case subjects, the substantial heterogeneity of the tumors, inconsistencies in histological diagnoses, definitions and groupings, and difficulties inherent in retrospective analyses.

The authors of the accompanying original paper present the descriptive epidemiology of glial tumors in the Jewish population in Israel [4]. This was a national prospective survey (planned as part of INTERPHONE multinational case-control studies, which investigated the association with cell phone use) examining gliomas diagnosed between March 2001 and July 2003, with histological classification. Though the data analyzed in this study were consistent with previous reports, they have provided useful information in the neurooncology literature regarding the epidemiology of gliomas.

Gliomas are more common in males with a male-to-female ratio of 1.5:1 [5]. When malignant, $80 \%$ of gliomas are glioblastomas [6]. Glioblastoma, the most common type of glioma, is associated with very poor survival, so glioma epidemiology has focused on identifying factors that can be modified to prevent this disease.

Except for infants, the prognosis of patients with these tumors is inversely related to age at onset, with older individuals having a poorer prognosis. In addition to age, anatomic distinctions are extremely important in the evolution and prognosis of these tumors.

Only two relatively rare factors have so far been conclusively shown to affect glioma risk - exposure to high doses of ionizing radiation and inherited mutations of highly penetrant genes associated with rare syndromes [7]. Different studies continue to suggest that brain tumors might result from occupation, dietary and other personal and residential exposures, but studies of cell phone use and power frequency electromagnetic fields have found little to support a causal connection with brain tumors; caveats remain though [8]. Previous studies have reported inconsistent results regarding the effect of anthropometric and lifestyle factors on the risk of developing glioma. A recent prospective cohort study of 1.3 million middle-aged women from the UK suggested the role of increasing height and BMI in the increasing incidence of glioma [9]. On the other hand, preliminary evidence points to a lower glioma risk among people with allergic conditions and high levels of serum IgE [7].

Progress in the understanding of gliomas will continue to result from studies of well-defined histological and molecular tumor types, incorporating the assessment of potentially relevant information on patient susceptibility and environmental factors. Such studies will require the cooperation of researchers from different disciplines.

\section{References}

1 CBTRUS annual report: primary brain tumors in the United States 1998-2002. http://www.cbtrus.org/ (accessed January 23, 2008).

2 Kleihues P, Louis DN, Scheithauer BW, et al: The WHO classification of tumors of the nervous system. J Neuropathol Exp Neurol 2002;61: 215-225.

3 Louis DN, Stemmer-Rachamimov AO: Pathology and classification; in Bernstein M, Berger M (eds): Neuro-Oncology: The Essentials. New York, Thieme Medical Publishers, 2000, pp 18-29.

-4 Sadetzki S, Zach L, Chetrit A, Nass D, Hoffmann C, Ram Z, Zaaroor M, Umansky F, Rappaport ZH, Cohen A, Wald U, Rothman S, Hadani M: Epidemiology of gliomas in Israel: a nationwide study. Neuroepidemiology 2008;31:264-269.

5 Inskip PD, Tarone RE, Hatch EE, et al: Cellular telephone use and brain tumors. N Engl J Med 2001;344:79-86.

-6 Walter AW, Hancock ML, Pui CH, et al: Secondary brain tumors in children treated for acute lymphoblastic leukemia at St Jude Children's Research Hospital. J Clin Oncol 1998;16:3761-3767.

7 Schwartzbaum JA, Fisher JL, Aldape KD, Wrensch M: Epidemiology and molecular pathology of glioma. Nat Clin Pract Neurol 2006;2:494503.

8 Wrensch M, Minn Y, Chew T, Bondy M, Berger MS: Epidemiology of primary brain tumors: current concepts and review of the literature. Neurooncology 2002;4:278-299.

-9 Benson VS, Pirie K, Green J, Casabonne D, Beral V, Million Women Study Collaborators: Lifestyle factors and primary glioma and meningioma tumours in the Million Women Study cohort. Br J Cancer 2008; 99:185-190.

Olufemi E. Idowu, MBBS, MSc, FWACS

Division of Neurological Surgery, Department of Surgery

Lagos State University College of Medicine and Lagos State

University Teaching Hospital

Ikeja, Lagos State (Nigeria)

Tel. +234 8023451 369, E-Mail oeidowu412@yahoo.com

\section{KARGER}

Fax +41613061234 E-Mail karger@karger.ch www.karger.com
(C) 2008 S. Karger AG, Base

0251-5350/08/0314-0270\$24.50/0 